\title{
Intracranial Germ Cell Tumour with extra cranial extension in a four month old infant - a case report
}

\author{
Laishram Jaichand Singh ${ }^{*}$, Sudha Reddy ${ }^{f}$, Khaidem Ibochouba $\operatorname{Singh}^{f}$
}

\begin{abstract}
Abstrak
Tumor sel germinal sistem saraf pusat yang menginfiltrasi jaringan ekstrakranial ipsilateral jarang terjadi. Dilaporkan satu kasus pada bayi berumur 4 bulan. Pasien menjalani eksisi lesi ekstrakranial dilanjutkan dengan kemoterapi kombinasi. Duabelas bulan setelah terapi kondisi pasien baik. (Med J Indones 2005; 14: 179-83)
\end{abstract}

\begin{abstract}
Germ cell tumours of the central nervous system infiltrating the ipsilateral extracranial tissues are not a common presentation. A case of intracranial germ cell tumour with extracranial extension in a four month old infant is reported. The patient had undergone excision of the extracranial lesion followed by combination chemotherapy. Twelve months after the completion of the treatment the patient is doing fine and is on regular follow up. (Med J Indones 2005; 14: 179-83)
\end{abstract}

Keywords: germ cell tumour, extracranial extension, management

Germ Cell Tumours (GCTs) of the central nervous system are rare and account for only $1-2 \%$ of all pediatric brain tumours with a peak incidence in 1012 years of age. ${ }^{1}$ However, it accounts for $4.8 \%$ of childhood brain tumours in $\mathrm{Japan}^{2}$ and $11.1 \%$ in Taipei. ${ }^{3}$ About two thirds of intracranial GCTs are germinomas and the rest are nongerminomas with a mixture of yolk sac tumour, choriocarcinoma or teratocarcinoma. ${ }^{4}$ In this report the clinical course, histopathological findings, tumour markers and radiological findings of a mixed malignant germ cell tumour of the brain with extracranial extension in a 4month-old infant is described. This is reported because of its rarity and its unique way of presentation.

\footnotetext{
* Department of Radiotherapy, Regional Institute of Medical Sciences, Imphal - 795004, India

$f$ Department of Pediatrics, Regional Institute of Medical Sciences, Imphal - 795004, India
}

\section{CASE REPORT}

A 4 month old male, mongoloid child, fifth in birth order presented with a mass in the right preauricular region with feeding difficulty. The mother was 34 years old and there was no history of consanguinity. On prenatal ultrasonography congenital abnormality of head with hydramnios was detected for which the child was delivered by caesarean section at term. The child was born with a huge mass arising from the right upper neck involving the parotid area, which was subsequently excised eleven days after birth and was diagnosed to be cystic hygroma. The child was doing well for about one month following surgery after which the parents noticed a swelling over the right temporal region, which was gradually increasing in size. Attempted surgical excision failed to remove the mass completely as it was found to be infiltrating the underlying skull bone. So only partial excision of the tumour mass was done. Right facial nerve had to be sacrificed to get a wider excision. The excised tissue was histologically reported as Mixed Malignant Germ Cell Tumour with bone involvement (Figure 1). The patient was subsequently referred to the Department of 
Radiotherapy, Regional Institute of Medical Sciences for further management alongwith C.T. scan of brain showing a mass over the right temporoparietal region with areas of calcification and features of bone involvement (Figure 2). There was significant enhancement with intravenous contrast, however MRI could not be done.

On physical examination, the child was lethargic and dehydrated. A diffuse globular swelling over the right temporoparietal region, with areas of ulceration, necrosis and foul smelling discharge in the right superior portion of retroauricular groove was noted. The child weighed $6 \mathrm{Kg}$ and head circumference measured 44 $\mathrm{cms}$. Anterior fontanel was soft and depressed and there were no diastases of sutures. The testes were normal. All other systems were clinically normal.

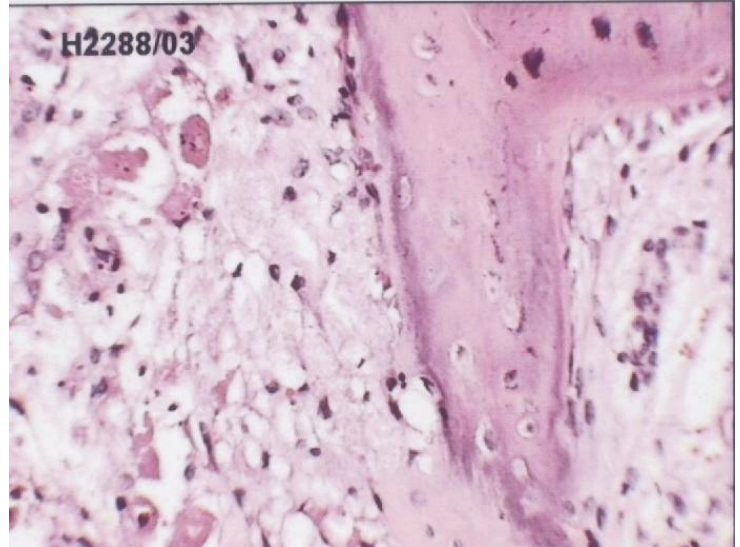

a
Routine hematological and biochemical studies were within normal range. Review of the histopathological slides of the excised tissue revealed features of malignant GCT with evidence of bone destruction. XRay chest and ultrasonography of whole abdomen did not reveal any positive findings. Serum alpha fetoprotein (AFP), beta subunit of human chorionic gonadotropin $(\beta-\mathrm{hcg})$ and carcino-embryonic antigen showed values of $1,64,181.27 \mathrm{ng} / \mathrm{ml}, 194 \mathrm{mIU} / \mathrm{ml}$ and $0.39 \mathrm{ng} / \mathrm{ml}$ respectively. Cerebrospinal fluid study did not reveal any malignant cells. Considering the clinical findings and the investigation reports, a diagnosis of Mixed Malignant Germ Cell Tumour of brain arising from the temporoparietal (supratentorial) area with extra cranial spread was entertained.

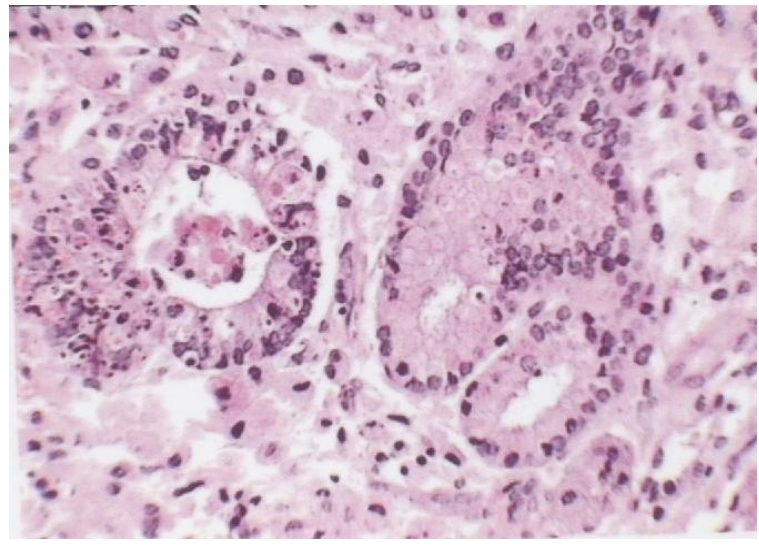

b

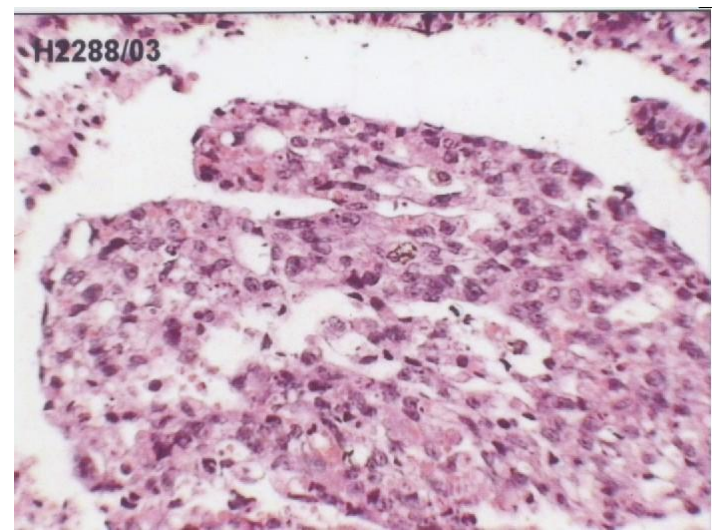

c

Figure 1. Microphotograph showing ( $H \& E, X 40$ )

a) undifferentiated mesenchymal tissue and bony trabeculae, b) glandular differentiation, c) glomeruloid body 


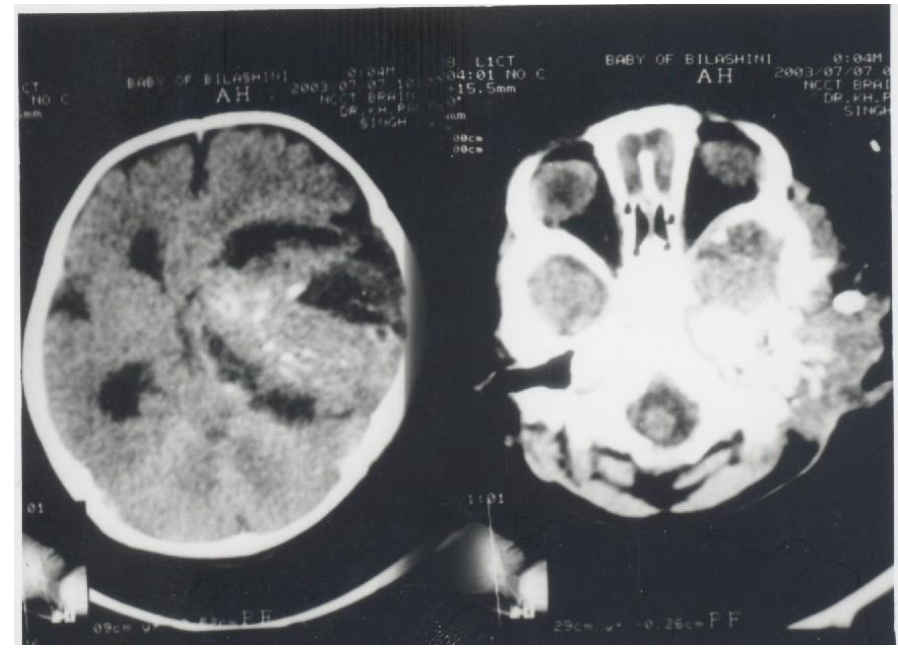

Figure 2. C.T. Scan of brain showing soft tissue lesion with calcification over the right temporoparietal region and erosion over the right temporal bone

For the initial few days the infant received parenteral fluids, nasogastric feeds and parenteral antibiotics (ceftriaxone, amikacin, metronidazole). During the supportive care, the mass increased in size distorting the right side of the face. Chemotherapy was started with Inj. Cisplatin $-100 \mathrm{mg} / \mathrm{m}^{2}$, Inj Vincristine -1.5 $\mathrm{mg} / \mathrm{m}^{2}$ and Inj. Bleomycin -15 unit $/ \mathrm{m}^{2}$ alternating with Inj. Carboplatin $600 \mathrm{mg} / \mathrm{m}^{2}$, Inj Etoposide $120 \mathrm{mg} / \mathrm{m}^{2}$ and Inj Bleomycin - 15 unit $/ \mathrm{m}^{2}$ at 4 weekly intervals. Following two cycles of chemotherapy, the mass decreased in size significantly and the child was able to take oral feeds. The ulceration over the right retroauricular groove also healed up (Figure 3). Subsequent cranial CT scans showed a grossly reduced mass over the right temporo-parietal area as compared to the previous scan and serum tumour markers showed a reduced level of AFP to 5198.95 $\mathrm{ng} / \mathrm{ml}$ with total absence of $\beta$-hcg. The child have already completed six cycles of chemotherapy as per the schedule. The last AFP value at the completion of chemotherapy was $17.79 \mathrm{ng} / \mathrm{ml}$. Twelve months after the completion of the chemotherapy the patient is still doing well, however he has delayed developmental milestones.

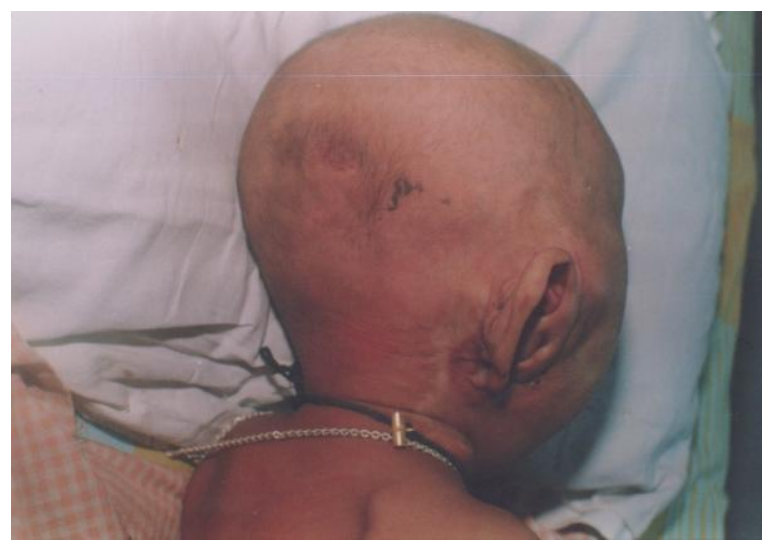

Figure 3. Photograph of the patient showing the healed up lesion over the right retroauricular groove and the partially regressed swelling confined to right temporal and parotid regions 


\section{DISCUSSION}

Primary Intracranial Germ Cell Tumour (ICGCT) is an uncommon disease. The commonest sites of occurrence in decreasing order of frequency are Pineal Gland $(62 \%)$, Suprasellar $(31 \%)$, involving both the areas $(7 \%) .{ }^{4}$ Occurrence of ICGCTs in uncommon sites such as basal ganglia and thalamus have also been reported in older children and adolescents. ${ }^{5,6,7,8}$ The age distribution was $5-15$ years in Taipei. ${ }^{3}$ These tumours are seen to occur in the basal ganglia and thalamus in about $10 \%$ of all intracranial germinomas. ${ }^{2}$ In the present case the tumour involved the suprasellar region with extensive involvement of right cerebrum extending extra cranially to the area around the right ear. To the best of our knowledge this is probably the first case of malignant mixed ICGCT with extra cranial spread presenting as a mass around the right ear in an infant to be reported. Malignant ICGCT is predominantly a tumour of adolescents and young adults, ${ }^{5,9,10,11,12,13,14,15}$ although its occurrence in younger children have also been reported., ${ }^{3,16,17}$ In infants these tumours are rare and review of available literature revealed a case of congenital mixed malignant ICGCT in a 27 weeks old male fetus involving brain and orbit. ${ }^{18}$

The clinical presentation varies according to the site involved, growth pattern and tumour histology. The symptomatology may include visual disturbance, diabetes insipidus, hypopituitarism, anorexia, precocious puberty etc. Mental changes, hemiparesis, oculomotor palsy, speech disturbances may also be seen. ${ }^{2}$

Germ Cell neoplasm may arise either directly from primordial germ cells or indirectly through embryonic or extra embryonic differentiation. The extragonadal origins (including the brain) are as a result of aberrant patterns of germ cells migration. The most common location of extragonadal GCT is the sacrococcygeal region followed in decreasing order of frequency by the mediastinal, intracranial and retroperitoneal regions. ${ }^{4}$ Of all childhood GCTs, teratomas are the most frequently encountered; majority of them behaving in a benign fashion. There can be a combination of both benign and malignant tissues and also nongerminomatous components in the tumour.

In young children, yolk sac tumours rarely occur in pure form in extragonadal sites and are more frequently a component of mixed malignant GCTs. In the present case, a predominance of malignant yolk sac component with abnormally high levels of AFP and $\beta$-hcg was found. The origin of $\beta$-hcg was probably due to the presence of trophoblastic tissue, which was not detected histopathologically, suggesting the nonhomogenous distribution of tissue components.9 Germ Cell tumour may also be composed of both benign and malignant tissues and it is the malignant components that determines the outcome of the patient. The malignant tissues may exist either in a pure form or in a mixed form consisting of many other malignant components. 4 So, a detailed histological examination of the resected specimen is required to come to a definite diagnosis. Extra neural metastasis of primary intracranial nongerminomatous GCT to the lung in a 14-year-old girl have been reported. ${ }^{10}$

Diagnosis of the condition depends mainly on imaging studies followed by a histological study of the specimen. The main modality of treatment is surgery followed by combination chemotherapy with or without radiation therapy. ${ }^{4}$ The duration of therapy is determined by the normalization of the tumour markers where that was raised. ${ }^{19}$ In children with malignant ICGCTs substantial improvement in symptoms, regression in tumour size and decrease in concentration in tumour markers have been reported with various treatment modalities including surgery, chemotherapy, and radiation. ${ }^{8,11,12,13,20}$ Chemoradiation have also been tried in some cases with good results ${ }^{8,13}$ but the overall prognosis of malignant ICGCTs in the pediatric age group still remains poor.

Intra cranial surgery was not attempted in the present case because of the diffuse nature of the tumour and also the poor general condition of the patient. Combination chemotherapy resulted in a remarkable regression of the tumour mass and decrease in concentration of both the tumour markers.

Except for the right facial nerve palsy and delayed developmental milestones there was no focal neurological deficit. The current case suggests that GCTs may be considered in the differential diagnosis of mass presenting in the head even if it is not situated in the midline.

\section{CONCLUSION}

A very uncommon type of Intracranial Germ Cell tumour with involvement of the ipsilateral cranial bones and soft tissues in a four month old infant is reported. Role of chemotherapy is stressed. The role of Radiation therapy in this age group and in the 
disease is not well defined as yet. Such a lesion may also be considered in the differential diagnosis of a mass presenting in the head even though it is a remote possibility.

\section{REFERENCES}

1. Kuttesch JF, Ater Jr, Ater JL. Brain Tumors in childhood. In: Behrman RE, Kliegman RM, Jenson HB, editors. Nelson Textbook of Pediatrics. $17^{\text {th }}$ ed. Philadelphia: Saunders Curtis Centre; 2004. p. 1702- 9.

2. Yasue M, Tanaka H, Nakajima M, Kamio M, Nakamura N, Numoto T, Tanaka J. Germ Cell Tumours of the Basal Ganglia and Thalamus. Pediatr Neurosurg 1993; 19: 121-6.

3. Lin IJ, Shu SG, Chu HY, Chi CS. Primary intracranial germ cell tumor in children. Zonghua Yi Xue Za Zhi 1997; 60(5): $259-64$

4. Castelberry RP, Cushing B, Perlman E, Hawkins EP. Germ cell tumors. In: Pizzo PA, Poplack DG, editors. Principles and Practise of Pediatric Oncology. $3^{\text {rd }}$ ed. Philadelphia: Lippincott-Raven Publishers; 1997. p. 921 - 43.

5. Kishima H, Shimizu K, Miyao Y, Mabuchi E, Hayakawa T. Possible common origin of alpha fetoprotein and human chorionic gonadotropin secreting cells in Intracranial germ cell tumor. Case report. J. Neurosurg 1998; 88(3): $576-80$.

6. Furuhata S, Yamada F, Fukuda S, Otani M, Toya S. Mixed germ cell tumor of the basal ganglia: a case report. Surg Neurol 1994; 41(6): 490 - 3.

7. Takano T, Matsui E, Yamano T, Shimada M, Nakasu Y, Handa J. Sequential MRI findings in a patient with a germ cell tumor in the basal ganglia. Brain Dev 1993; 15(4): $283-7$.

8. Miyamachi K, Aida T, Abe H. Five cases of primary intracranial germ cell tumor treated by combination chemotherapy with cisplatin. No ShinkeiGeka 1988; 16(9): $1053-8$.

9. Ikura Y, Sasaki M, Ohgami M et al. Mixed germ cell tumor of the brain. Pathologic study of six autopsy cases. Pathol Res Pract 1996; 192(6): 595 - 603.
10. Berek K, Aichner F, Schmutzhard E, Kofler M, Langmayr $\mathrm{J}$, Gerstenbrand F. Intracranial germ cell tumor mimicking anorexia nervosa. Klion Wochenschr 1991; 69(10): 440 - 2.

11. Watterson J, Priest JR. Control of extraneural metastasis of a primary intracranial nongerminomatous germ cell tumor. Case report. J Neurosurg 1989; 71(4): $601-4$.

12. Yuki K, Kodama Y, Emoto K, Yukawa O, Onda J, Uozumi T. A case report of advanced malignant germ cell tumor of parasellar origin indicating marked efficacy of a salvage combined chemotherapy of CDDP and etoposide and subsequent chemotherapy using oral etoposide. Gan To Kagaku Ryoho 1989; 16(8): 2651 - 4.

13. Yuki K, Kodama $\mathrm{Y}$, Onda $\mathrm{J}$ et al. A case of primary intrasellar malignant germ cell tumour. Gan No Rinsho 1988; 34(15): $2091-5$.

14. Bruyland M, Peters O, Schallier D et al. Periventricular metastases of a primary intracranial alpha fetoprotein producing germ cell tumor. Eur Neurol 1986; 25(3): 172 - 6 .

15. Norgaard - Pedersen B, Lindholm J, Albrechtsen R, Arebnds J, Diemer NH, Riishede J. Alpha fetoprotein and human chorionic gonadotropin in a patient with a primary intracranial germ cell tumor. Cancer 1978; 41(6): 2315 - 20.

16. Nishiyama $K$, Nishida $K$, Kusaka $K$, Morizumi $H$. Primary intracranial malignant germ cell tumor associated with abnormal high value of alpha fetoprotein and human chorionic gonadotropin. No Shinkei Geka 1987; 15(12): $1337-42$.

17. Hokin K, Abe H Aida T, Mabuchi S, Tsuru M, Nakamura N. Primary intracranial germ cell tumor with high value of alpha fetoprotein after the radiation therapy. No Shinkei Geka 1983; 11(2): $217-21$.

18. Lee JC, Jung SM, Chao AS, Hsueh C. Congenital mixed malignant germ cell tumor involving cerebrum and orbit. J Perinat Med 2003; 31(3): 261 - 5 .

19. Oncology and Terminal Care. In Campbell AGM, Mc Intosh $\mathrm{N}$ editors. Forfar and Arniel's Textbook of Pediatrics. $5^{\text {th }}$ ed. Edinburgh: Churchill Livingstone; 1998. p. $884-933$.

20. Castaneda VL, Parmley RT, Geiser CF, Saldivar VA, Mullins JK, Marlin AE. Postoperative chemotherapy for primary intracranial germ cell tumor. Med Pediatr Oncol 1990; 18(4): 299 - 303. 